\title{
Social Capital in Natural Disaster Management; A Case Study of Social Capital in Padang City
}

\author{
Anita Afriani Sinulingga*, Silsila Asri, Virtuous Setyaka, Putiviola Elian Nasir, and Rika Isnarti \\ Department of International Relations, Faculty of Social dan Political Sciences, Andalas University, Padang, \\ Indonesia \\ *E-mail: nanisinulingga@gmail.com
}

\begin{abstract}
The purpose of this paper is to describe social capital in disaster management in the city of Padang. West Sumatra and specifically Padang have four of the largest potential natural disasters such as earthquake, tsunami, landslides, and floods. The huge potential of natural disasters in West Sumatra has caused the province to be dubbed the Disaster Laboratory. As a disaster-prone area, various forms of humanitarian assistance have been received from international institutions. Recently it is a great concern to the world community. Talking about international humanitarian aid, the Indonesian government issued One Door Policy in selecting foreign aid related to disaster management. This study used a qualitative approach with in-depth interview data collection and documentation study. Padang City was chosen as a research location because the city is one of the most vulnerable areas in West Sumatra. This paper concludes that disaster management in the city of Padang involving the three social capital but the cohesiveness between social capital is not strong enough.
\end{abstract}

Keyword: social capital; disaster management; Padang

\section{INTRODUCTION}

Recently problems relating to a natural disaster are not only a state concern but also have become global affairs. A series of natural disasters such as Aceh' earthquake and tsunami in 2004, the earthquake in West Sumatra in 2009, the volcano eruption in Yogyakarta in 2013 has invited the international community to provide humanitarian assistance and post-disaster recovery. Aceh earthquake and tsunami in 2004 was one of an example high number and involvement of international agencies. MultiDonor Fund for Aceh and Nias (MDF) which established in April 2005 played a significant role in coordinating donor assistance in the context of reconstruction and rehabilitation of earthquake and tsunami affected areas in December 2004 and the subsequent earthquake of March 2005. The MDF managed to collect US \$ 655 million in grants from 15 donors in which the World Bank acted as Trustee for the MDF. In that amount, the MDF funds 23 projects in six areas of community recovery, recovery of transport and large-scale infrastructure, strengthening governance and capacity building, environmental conservation, improvement of recovery processes, and economic and livelihood development (World Bank, 2012).

There are many reports and research on disaster response and the process of reconstruction and rehabilitation of the West Sumatra earthquake disaster on 30 September
2009. One of the references in this study is a book published based on research results and reports published by the National Disaster Management Agency, entitled 'Lesson Learned: Learning RehabRekon Post Earthquake in West Sumatra, 30 September 2009'. The book is written by Sugimin Pranoto, et al., it describes the involvement of local and international NGOs, community-based organizations, and the United Nations agencies in emergency response, early recovery, and rehabilitation and reconstruction efforts to support the humanitarian and redevelopment the area that has been done by the government (Pranoto, 2011).

The Indonesian government has experienced a change of perspective on foreign aid on disaster issues. Although Indonesia is not blocking or refusing foreign aid from the global community, the Indonesian government is now more selective in receiving foreign aid. Before the Indonesian government implemented the Open Door Policy on overseas aid to anticipate and mitigate disaster risk but nowadays it regulates the One Door Policy. One of the fundamental differences in the policies is that the foreign aid must pass through the National Disaster Management Agency (BNPB) as a focal point in disaster management in Indonesia. If in the earlier policy, international donors are more flexible and can directly provide assistance to local NGOs and communities, in the latest policy these international institutions should pass the 
aid through BNPB and are required to adapt to the rules of disaster management in Indonesia.

Natural disasters become a political thing when entering the realm of policy-making. The policy of accepting or rejecting international humanitarian aid is a form of state behavior that considers many things, including national interests, capabilities, threats, and opportunities faced by the country as proposed by Viotty and Kauppi (2013). The choice of countries to build bilateral and multilateral cooperation in managing disasters is also based on national capabilities as well as consideration of threats that may be accepted by the state. Self-sufficiency is a term often used in a country that seeks to rely on national resources and minimize humanitarian aid interventions. Within the framework of the country's behavior described by Viotty and Kauppi above, social capital occupies the carrying capacity of the state capability both nationally and locally.

\section{LITERATURE REVIEW}

The concept of social capital was originally a concept developed in the study of sociology, but in its development, it is used in other studies such as politics and economics. According to Robert Putnam, social capital refers to the collective value of all social networks and a strong desire to engage and do everything in order to realize their own interests. Putnam also distinguishes two categories of social capital namely bonding capital and bridging capital. Social capital in the form of bonding (binding) seen in a homogeneous community is analogized as a form of socialization with people with the same age, race, religion, and others. However, to create a peaceful society in a multi-ethnic country, a second social capital model called bridging capital is needed. It is illustrated as a connection or bridge to build and make friendships with people from different communities (Putnam, 2000). These two forms have their respective strengths. From the above explanation, it can be understood that social capital is a value or norm that is recognized collectively so as to encourage the emergence of mutual trust and reciprocal relationships by involving institutions in society.

In addition, Woolcock distinguishes three types of social capital into bonding, bridging, and linking types. Bonding social capital is the bond between people who have a number of similar situations such as close family, close friends, and neighbors. This type of social capital works more internally and solidarity built, therefore, leads to more microcosmic and communal social cohesion because the relationships within it are more exclusive. Bridging social capital reaches further ties with distant friends and colleagues. This type is more inclusive with more networking with external potential attached to it. Linking social capital includes a wide range of people who are not in the same situation as those living outside the community; this community has a wider range of available resources (Woolcock, 2002). This social capital moves on a wider level because they no longer distinguish their class and social status.

Narayan and Cassidy (2001) indicate social capital using 7 (seven) indicators to measure the availability of social capital. The seven indicators are: (a) group characteristics (including membership number, contribution of funds, frequency of participation, participation in decision making, membership heterogeneity, funding source for the organization); (b) general norms (including the willingness to help others, caring for others, openness to others); (c) togetherness (including as many people can live together, the level of togetherness among people); (d) daily socialization; (e) neighboring relationships (including the willingness to ask neighbors to care for a sick child or to help themselves who are ill); (f) voluntarism (including whether to work as a volunteer, expectations of volunteering, criticism of those who refuse volunteer work, contribution to the neighborhood, whether to help others); and (g) trust (including trust in families, neighbors, people from different classes, business owners, government officials, law enforcers, such as prosecutors, judges, and police) to local government officials). 


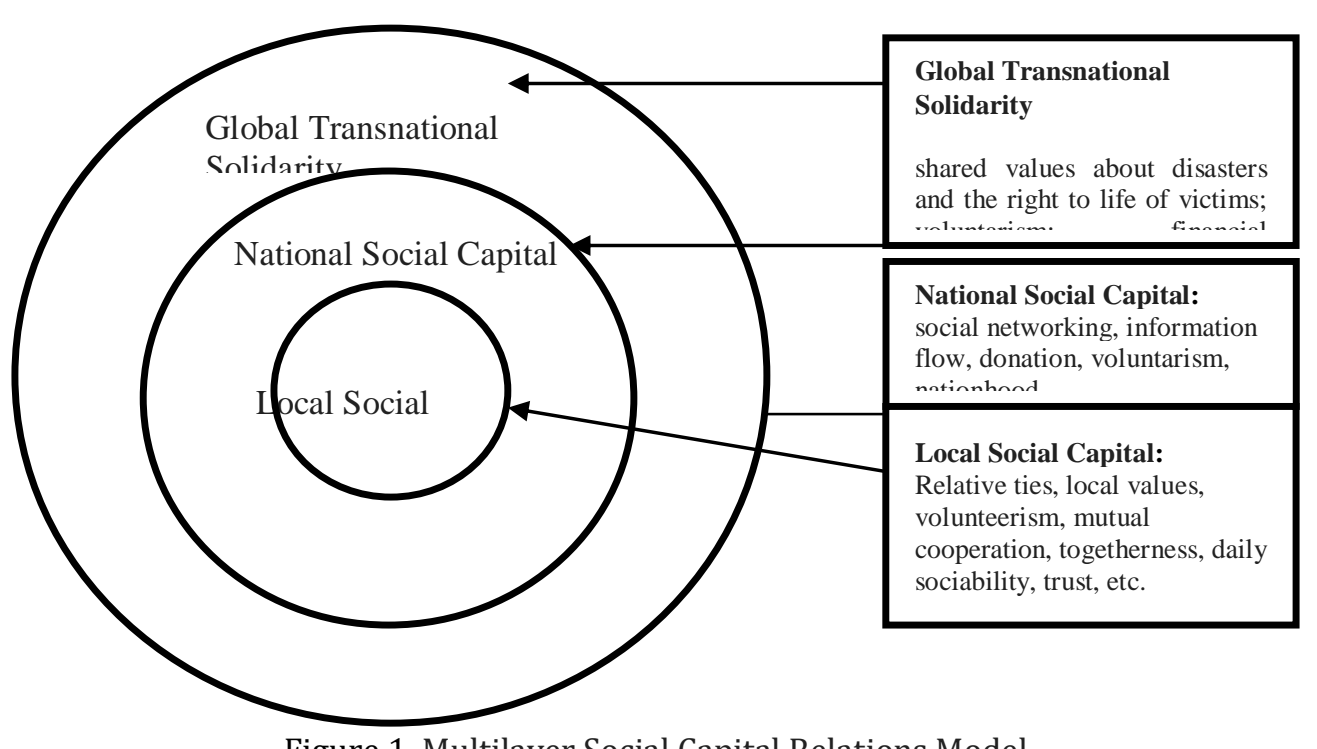

Figure 1. Multilayer Social Capital Relations Model

The power of the social capital dimensions varies each other. Bonding social capital reaches all of the dimensions of social capital. The frequency and intensity of interaction bring together values and practices of mutual assistance, togetherness, daily sociality, volunteerism and trust in local institutions, while in social capital bridging and social capital linking reaches some of these dimensions. Transnational solidarity reflected through international institutions can be categorized as linking social capital. As their reach across national boundaries, transnational solidarity has the potential to mobilize diverse resources in the global context of the financial resources, drugs, medical and technological needs of disaster victims. National solidarity is also equipped with a global knowledge of disaster management experience in various regions and strategic approaches that have been adopted in disaster management. In the issue of disaster management, transnational emotional bonds provide wider access to disaster relief assistance resources that limit national and local social capital (Hermawan, 2012). More specifically, the layers of social capital can be seen in Figure 1.

\section{RESEARCH METHOD}

This research is a qualitative research and design in the form of descriptive research. Data in this research is primary data and secondary data. Primary data is data obtained from direct interviews of subjects or informants. While secondary data is data obtained from archives or documentation relevant to the research problem. The selection of informants was done using purposive sampling technique. Informants in this research are related parties and involved directly related to research problems are local NGOs and community groups, local disaster management agency (BPBD) West Sumatra Province and international donor agencies that have programs in disaster issues in West Sumatra. For data collection, this study used interview techniques and documentation study books, journals, research reports, agency activities reports, working papers related to issues in research. Meanwhile, to obtain validity of data maximally, analysis of research data is done by triangulation technique of source (information).

\section{DISCUSSION}

Referring to the three types of social capital proposed by Woolcock namely social capital bonding, bridging social capital and linking social capital, and based on seven indicators to measure social capital proposed by Narayan and Cassidy, this study aims to explain the synergistic and collaboration that formed during the process of rebuilding West Sumatera after the earthquake in 2009. Disaster management effort is a collaboration between the local community as bonding social capital, Local Government and/or local government agencies (SKPD) that are Regional Disaster Management Agency as bridging social capital, and international donor institution which is linking social capital.

This study divides four phases of the community recovery process after the earthquake of West Sumatera on 30 September 2009, namely the phase of the emergency response phase, the early recovery phase, the rehabilitation and reconstruction phase and the disaster preparedness phase. At each phase, social capital that works significantly looks 
differently. The availability of social capital in the community of Padang or the Minangkabau community, in general, is strongly influenced by the prevailing norms, including customary norms, religious norms and legal norms related to government regulations. For all four recovery phases, the three types of social capital work simultaneously with different intensities.

In the emergency response phase that lasted from September 30, 2009, to November 30, 2009, social capital bonding is seen as not working significantly compared to bridging social capital and social linking capital although the communal and philosophical system exists Minangkabau in terms of mutual cooperation. This condition is caused by the panic of residents who overridden the disaster and more concerned with self-saving and their families. The results of interviews with one of the victims mentioned that the first aid he received during the earthquake occurred was from an international donor agency. Thus, it can be concluded that social capital linking in the emergency response period is very helpful in the evacuation and rescue process of disaster victims.

During the emergency and early recovery period, there are 130 international agencies providing humanitarian assistance. The involvement of international agencies and nongovernmental foreign agencies is coordinated by United Nations Office for the Coordination of Humanitarian Assistance (UNOCHA). Most of the activities of international donor agencies ended at the end of December 2009, after the emergency response period expired by the government. However, UNOCHA is continuing its activities to bridge or connect the cooperation of international donors involved in the early recovery period and the beginning of the rehabilitation and reconstruction process from January 2010 to April 2010. International donors who are still participating in the rehabilitation and reconstruction process until March 2011 are located under the coordination of United Nations Office for the Humanitarian / Resident Coordinator (UN RC / HC). The humanitarian activities undertaken cover the various fields that are divided into 9 clusters.

At the end of December 2009, humanitarian activities conducted by international parties in West Sumatra gradually began to decrease. Thus, part of the cluster activity of the emergency response phase has stopped and some international humanitarian actors transformed from emergency response to early recovery. This early recovery activity is actually the beginning of the government-run rehabilitation and reconstruction process. To facilitate coordination, international agencies and non-governmental foreign institutions participating in the early reconstruction and rehabilitation process must register their participation by submitting activity proposals and agency profiles to the government. There are 54 international and non-governmental institutions participating in the early and early recovery process of rehabilitation and reconstruction. International humanitarian activities are still coordinated in cluster form, but their coordination is under UN RC / HC through the establishment of Early Recovery Network (ERN). In the mid of 2010, international humanitarian activities ended and the implementation and responsibilities of working groups began to be transferred to the relevant government agencies.

In the rehabilitation and reconstruction phase that runs from December 1st, 2009 until 2011. The period of disaster management was an action plan developed by the Regional Government, the Ministry of National Development Planning, Republic of Indonesia (Bappenas) and BNPB in cooperation with Andalas University. Rehabilitation and reconstruction activities are policies integrated into national and regional development planning systems so that the funding is sourced from state and sub-state budget (APBN / APBD). Donations from donor agencies are channeled through APBN / APBD. International donor agencies, international non-governmental organizations and local and national non-governmental agencies are also involved in the rehabilitation and reconstruction process. International donors not only provide funding but also technology, thinking, and idea and management assistance on disaster issues. The rebuilding of West Sumatra after the earthquake is done with communitybased development approach. In the implementation of the work plan every rehabilitation and reconstruction program is done by two methods namely contractual and community empowerment. Contractual in the sense of the project is done through a government contracted agency. In this case, aimed at rebuilding public buildings damaged by the disaster. While rebuilding housing, the economic and social conditions of the community are done by empowering communities through forming of community groups (Pokmas) that are responsible for the restoration of their respective community groups. 
Furthermore, it can be observed that three types of social capital work simultaneously in the post-earthquake rehabilitation and reconstruction process of West Sumatera 2009, especially in the city of Padang. The communitybased development model utilizes social capital bonding. Tribal cooperation and solidarity that have become common values are the sources of the availability of social capital bonding. The Minangkabau community has an unwritten customary norm that 'Kaba buruak bahambauan' which means every disaster (bad news) must be a common concern. In addition, the formation of Pokmas is the government's effort to empower the social capital of bonding.

Government as the main actor that decides, runs and controls the implementation of rehabilitation and reconstruction is a source for the availability of social capital bridging. Governments and related bodies both national and local become the bridge to the connectedness of social capital-social capital that exists in the utilization of post-disaster recovery. Therefore, social capital bridging plays a very significant role in the rehabilitation and reconstruction process of West Sumatra after the disaster. The government is also an entry point for social linking capital, which is international solidarity channeled through humanitarian aid from various international institutions.

The availability of social capital linking in the disaster in West Sumatra, especially with the post-2009 earthquake took place in a relatively short time when compared with the availability of social capital linking in other disaster-prone areas such as Aceh, West Java, and Yogyakarta. In short, the existence of transnational social capital is in line with the government's work plan in the post-disaster recovery process.

The fourth phase is the disaster preparedness phase. This phase is a phase after the end of the reconstruction and rehabilitation process. However, the real phase of disaster preparedness has started since before the 2009 earthquake occurred. Several local NGOs and non-governmental foreign agencies have been conducting activities in preparation for disaster preparedness in Padang before the 2009 earthquake. After 2011, disaster recovery activities in West Sumatra became the work of local government and local communities. In addition to the restoration of socio-economic conditions of the community, some routine and incidental activities for education prepared for disaster preparedness remain to be done. Most of them are local NGOs, non-governmental foreign agencies and governments through provincial and city BPBDs. Foreign non-governmental institutions that are still active in conducting disaster-related activities in West Sumatra after the earthquake, especially in Padang City, is Mercy Corps. Mercy Corps is a source of social capital linking in disaster preparedness education.

\section{CONCLUSION}

In the post-disaster period, consistency in disaster management activities is needed, especially in terms of preventing and strengthening preparedness in the face of similar situations. The community, through community forums concerned with disaster issues, has been seen as an active role in the post-disaster period. In its disaster activities, the community works well with the government through BPBD and international donor agencies. This research found that disaster management in Padang city involves the three social capital that is bonding social capital, bridging social and linking social capital which is reflected from the involvement of multidimensional actors that is Padang city disaster preparedness community, government, and international donor institution. However, there is a problem in terms of cohesiveness between social capital. Trust as a form of social capital is found in bonding social capital, between bonding social capital with bridging social capital, between bonding social capital with linking social capital. However, this study does not find strong relations between bridging social capital and linking social capital. It means that in the disaster issue, communities gain trust from the government through the involvement of communities in disaster preparedness, and international donor agencies through the provision of financial support and partnership activities in disaster activities. There is also no clear cohesiveness between the government and international institutions. Therefore, the government needs to find the right format in post-disaster governance in relation to international donor agencies. The main strengths of the donor agencies are in funding and experience in disaster management in various countries. 


\section{REFERENCES}

D. Narayan and M.F. Cassidy (2001), A Dimensional Approach to Measuring Social Capital: Development and Validation of a Social Capital Inventory, Current Sociology, Vol 49 (2)

Law on Disaster Management No.24 of 2007

M. Woolcock (2002), Social Capital in Theory and Practice Where Do We Stand? Chapter 2 en Isham, J., T, Kelly and S. Ramaswamy (Eds), Social Capital and Economic Development: Well-Being in Developing Countries, Cheltenham dan Northhampton, MA: Edward Elgar Publishing

P.R. Viotti and M.V. Kauppi (2013), International Relations and World Politics, United State of America: Pearson Education

R..D. Putnam (2000), Bowling Alone: The Collapse and Revival of American Community, New York: Simon and Schuster

S. Pranoto, et al. (2011) Lesson Learned: Pembelajaran Rehab Rekon Pasca Gempa di Sumatera Barat, 30 September 2009, Padang: Badan Nasional Penanggulangan Bencana

World Bank (2012), The Multi-Donor Fund (MDF) for Aceh and Nias: a framework for reconstruction through effective partnerships, MDF-JFR Working Paper series; 1 (5), p.17, Washington DC: World Bank Group

Y.P. Hermawan (2012), Mengelola Modal Sosial dan Solidaritas Transnasional dalam Penanganan Dampak Bencana Lokal, p. 97, in June Cahyaningtyas dan Ludiro Madu (eds), Isu Bencana dalam Hubungan Internasional, Yogyakarta: Graha Ilmu 